\title{
Vliv psychomotoriky na pozornost dětí s ADHD
}

\section{Influence of psychomotricity on attention of children with ADHD}

\author{
Tereza Louková ${ }^{1,}$ Marie Blahutková ${ }^{2}$ \\ ${ }^{1}$ Pedagogická fakulta, Univerzita J. E. Purkyně, Ústí nad Labem, \\ Česká republika \\ ${ }^{2}$ Fakulta sportovních studií, Masarykova univerzita, Brno, \\ Česká republika
}

\section{Abstrakt:}

Naše studie se zabývá vlivem intervenčního programu, který zahrnuje vybrané psychomotorické aktivity, na pozornost dètí mladšího školního věku $s$ ADHD. Cílem práce je ověrit vliv intervenčního programu na pozornost dèti mladšiho školního věku s ADHD. Jedná se o kvantitativně-kvalitativní př́padovou studii. Jako metodu sběru dat jsme použili Test pozornosti d2, Císelný čtverec, pozorování a interview. Pracovali jsme se 4 dětmi ve věku 9 až 10 let s ADHD. Testovali jsme změnu v koncentraci a rozsahu pozornosti pred a po aplikaci intervenčního programu. Intervenčni program byl zařazen do běžných hodin tělesné výchovy na základní škole u dvou čtvrtých tř́d. Zjistili jsme, že v koncentraci i rozsahu pozornosti došlo u dètí s ADHD k výraznému zlepšení.

\section{Abstract:}

This work deals with the influence of the intervention program, which includes psychomotor activities to the attention of the younger school-aged children with ADHD. The aim of the work is to validate the impact of the intervention program to the attention of the younger school-aged children with ADHD. We used the quantitative-qualitative case study. We used the methods of data collection Test of Attention d2, 
Test of Attention "Numerical Square", interviews and observation. We worked with 4 children in the age of 9 to 10 years with ADHD from 2 different classes of primary school. We tested the change in concentration and extent of the attention before and after application of the intervention program. We found out that concentration and extent of attention were significantly improved at each child.

Klíčová slova: psychomotorika, prožitek, pozornost, ADHD.

Key words: psychomotricity, experience, attention, syndrom ADHD.

\section{PROBLÉM}

Pro dnešní dobu je typická společnost s orientací především výkonovou. Už po vstupu do školy se dosavadní dětské hry mění v závod, kdo bude první, kdo bude nejlepší. Důraz je kladen především na intelektuální výkony, přirozený pohyb a prožitek z něj jsou odsouvány na vedlejší kolej. I proto přibývá dětí s různými problémy a poruchami. Jedním z nejčastějších, na který si stěžují učitelé i rodiče, jsou problémy s pozorností. Od nich se odráží další problémy, které se mohou projevovat $\mathrm{v}$ různých oblastech - sociálních vztazích, vztahu k sobě samému, pracovitosti, hyperaktivitě, nekázni, agresivitě apod. Přibývá dětí, u kterých se porucha pozornosti objevuji dokonce $\mathrm{v}$ diagnóze. V naší práci se soustředíme na děti se syndromem ADHD.

ADHD se vyznačuje poruchou systému motorického, percepčního, kognitivního a behaviorálního. Narušuje školní výkonnost dětí s normálním intelektovým potenciálem. Zásadním problémem těchto poruch jsou nepříznivé sociální důsledky. Hyperaktivní děti bývají často odmítány, zažívají kritiku a negativní hodnocení. Obvykle se v takových případech objevuje deprivace v oblasti citových potřeb a sociálního kontaktu, častý prožitek stresu a nízká míra frustrační tolerance. Výše uvedené okolnosti nepř́iznivě ovlivňují jejich motivaci, snahu a celkový osobnostní rozvoj (Weiss \& Hechtmann, 1993; Barkley, 2006; Shaywite, 1988; Americká Psychiatrická Asociace, 2000, Vágnerová, 2004; Malá, 2000). ADHD se 
často vyskytuje v prrítomnosti s jinou poruchou učení či chování. (Riccio et al., 1994; Merrel, 1990; Torgesen, 1988). Mezi nejdůležitější symptomy, které predikují vážnost syndromu ADHD, patří: nepozornost, emocionální labilita a problémy v chování. Další oblast, která bývá často u ADHD narušena je motorika (Brossard-Racine, 2011).

Jak uvádí Matějček (2005), neúspěchy v pohybových aktivitách jedinec $\mathrm{v}$ tomto období prožívá častokrát tíživěji než neúspěchy v učení, přestože si to rodiče a často ani učitelé nepřipouštějí. Nezřídka pak takové dítě bývá terčem posměchu, což komplexy, uzavírání do sebe, v některých případech i neurotické projevy, ještě více prohlubuje. Ve škole se to může projevovat právě nepozorností, impulsivitou, zvýšenou aktivitou (typické projevy ADHD).

Děti tělesně slabší je potřeba $\mathrm{k}$ pohybu vést nenásilně, za stálého a vhodného povzbuzování a soustavného uznání za každý pokrok. Rozvoj pohybové obratnosti je důležitý nejen pro zdravý tělesný a duševní vývoj, ale souvisí také s dovednostmi v psaní a kreslení, motorickými dovednostmi, tedy celkově s dovednostmi ve škole i mimo ni. Pedagogové by měli vytvářet takové prostředí, aby i jedinci méně zdatní mohli zažít pocit úspěchu, pocit sounáležitosti se skupinou.

Psychomotorické aktivity se jeví jako vhodná forma pohybových aktivit pro jedince, kteří nejsou v běžné tělesné výchově úspěšní, a jako vhodná forma stimulace pozornosti (Trávníková, 2008; Dvořáková \& Michalová, 2004; Kovářová, 2010).

\section{CÍL PRÁCE}

Cílem našeho výzkumu je ověřit vliv intervenčních programů, které obsahují psychomotorické aktivity, na změnu pozornosti u dětí mladšího školního věku s ADHD.

\section{VÝZKUMNÉ OTÁZKY}

VO1: Jak se změní koncentrace a rozsah pozornosti u dětí mladšího školního věku s poruchou pozornosti po provedení intervenčního programu? 
VO2: Jak se změní vztah k pohybové aktivitě u dětí s poruchou pozornosti po provedení intervenčního programu?

\section{METODIKA}

Pro naši studii jsme zvolili typ výzkumného plánu multikasuistickou př́padovou studii.

\section{Výběr a charakteristika respondentů}

Výběr souboru byl prostý záměrný. Pracovali jsme se 4 respondenty. Mezi kritéria výběru jsme zařadili účast v intervenčním programu alespoň ze $75 \%$, dle psychologických vyšetření výskyt ADHD, věk mezi 9 až 10 lety, chlapec nebo dívka. Věkový průměr činil 9,25 let. Respondenti byly součástí experimentální skupiny 41 dětí, jejichž průměrný věk činil 9,43 let.

\section{Použité metody}

Sběr dar probíhal pomocí testu pozornosti d2, Číselného čtverce, pozorování a polostrukturovaného rozhovoru.

\section{Intervenční program}

Intervenční program probíhal $1 \times 45$ minut týdně $\mathrm{v}$ rámci běžné tělesné výchovy s celou třídou v období záŕí 2011 až květen 2012. Celkem bylo realizováno 30 lekcí. Program obsahoval vybrané psychomotorické aktivity zaměřené především na rozvoj pozornosti (Blahutková, 2007; Adamírová, 2006; Dvořáková, 1995; Krejčí, 2003; Szabová, 1999, atd.). 


\section{VÝSLEDKY}

\section{Porovnání výsledků TO v celkovém výkonu Testu pozornosti d2}

\section{Porovnání výsledků v CV}

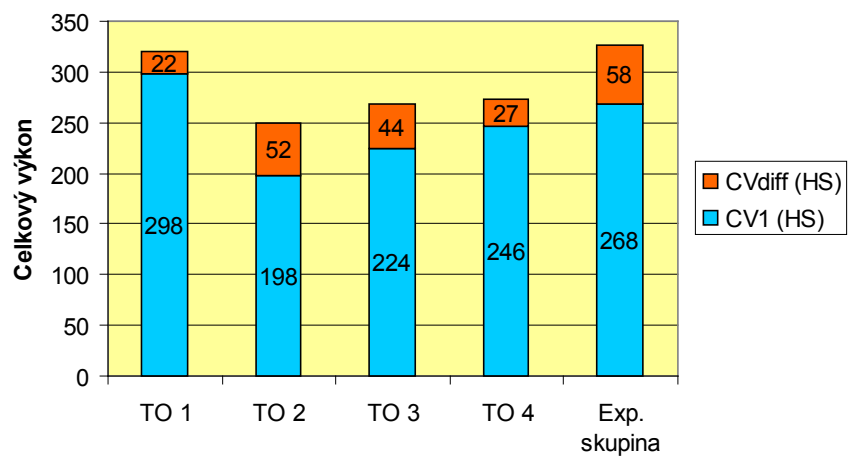

Obr. 1: Graf porovnání výsledků v celkovém výkonu

\section{Porovnání míry zlepšení v CV}

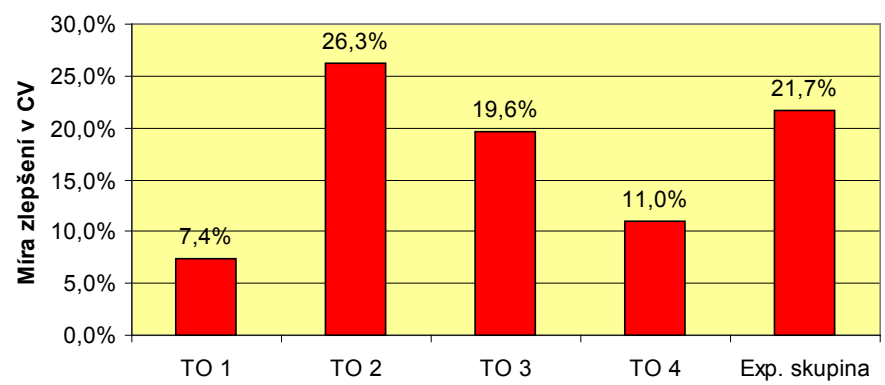

Obr. 2: Graf porovnání míry zlepšení v CV 
Vysvětlivky:

$C V(H S)$ - celkový výkon vyjádřený v hrubém skóru;

$C V(P E)$ - celkový výkon vyjádřený v percentilech;

$C V 1$ - prüměrný celkový výkon v pretestu (v 1. měřeni);

CV2 - prüměrný celkový výkon v posttestu (2. měrení);

$C V_{\text {diff }}$ - rozdil v celkovém výkonu mezi 1. a 2. měrenim;

Míra zlepšeni - procentuelni vyjádření změny v průměrném celkovém výkonu mezi 1. a 2. měřnim.

Z výše uvedených dat je patrné, že nejlepšího výkonu v pretestu dosáhla TO 1 (298 HS). Její výkon byl lepší i oproti průměru celé experimentální skupiny. Naopak nejhoršího výkonu dosáhl TO 2 (198 HS), který však zároveň dosáhl nejvyššího zlepšení (26,3 \%) oproti ostatním TO a zároveň oproti průměrnému zlepšení celé skupiny. Kromě TO 1, která již v pretestu měla vysoký skór v CV, došlo u všech TO k výraznému zlepšení a celkový výkon v posttestu se zlepšil. Kromě TO 1 byly výkony u ostatních TO v pretestu podprůměrné vzhledem k průměru skupiny, v posttestu došlo u všech ke zlepšení, ovšem výsledky v posttestu se nacházely pod průměrem celé skupiny.

\section{Porovnání výsledků TO ve výkonu soustř̌edění}

Porovnání výsledků ve VS

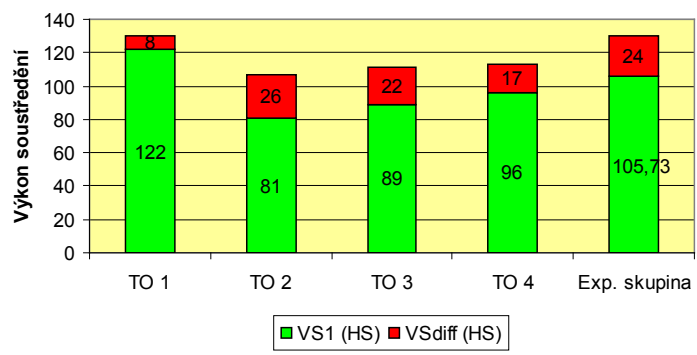

Obr. 3: Graf porovnání výsledkủ ve výkonu soustředění 


\section{Porovnání míry zlepšení ve VS}

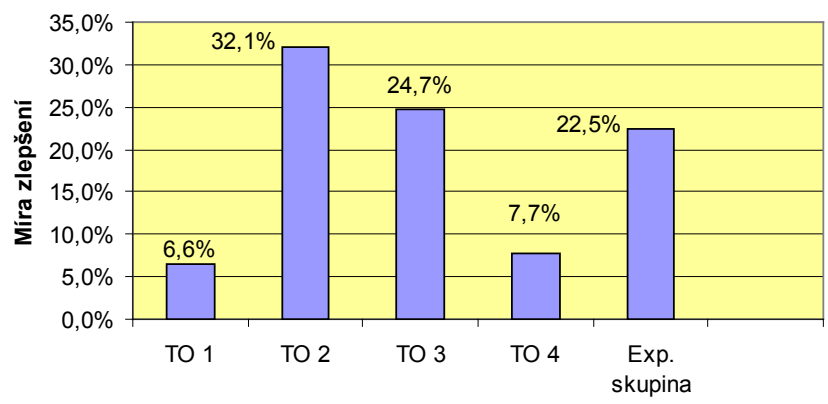

Obr. 4: Graf porovnání míry zlepšení ve výkonu soustředění

Vysvětlivky:

VS (HS) - výkon soustředění v Testu pozornosti d2 vyjádřený v hrubém skóru;

VSI (HS) - průměrný výkon soustředění v pretestu (1. testování) vyjádřený v hrubém skóru;

VS1 (PE) - průměrný výkon soustředèní v pretestu vyjádřený v percentilech;

VS2 (HS) - průměrný výkon soustředění v posttestu (2. testování) vyjádřený v hrubém skóru;

VS2 (PE) - průměrný výkon soustředění v posttestu vyjádřenýv percentilech;

$V S_{\text {diff }}(H S)$ - průmérný rozdil mezi pretestem a posttestem ve výkonu soustředèní;

Exp-experimentální skupina - 41 dètí (17 chlapců, 24 děvčat; prüměrnývěk 9,43 let);

Míra zlepšení - procentuelní vyjádřeni změny v průměrném výkonu soustředění mezi 1. a 2. měrenim;

TO-testované osoby (3 chlapci, 1 dívka, průměrný věk 9,25 let).

Z výše uvedených dat vyplývá, že nejlepšího výkonu v pretestu dosáhla TO 1 (122 HS). Její výkon je nadprůměrný oproti normě a zároveň je vyšší než průměrný výkon celé skupiny. Ostatní TO dosáhly v pretestu podprůměrných výkonů, především TO 2, jejíž výkon v pretestu spadá do percentilového pásma 10,0-25,0. U TO 2 můžeme pozorovat největ- 
ší míru zlepšení (32,1 \%). Svým výkonem v posttestu se vyrovnal TO 3 a TO 4, jejich výkon spadá do percentilového pásma 50,0-75,0. Nižší míry zlepšení dosáhla TO 1 a TO 4 . U TO 1 je hlavním důvodem již předchozí velmi dobrý výkon v 1 . měření.

Porovnání výsledků v průměrném čase v testu Číselný čtverec

Porovnání výsledků v průměrném čase

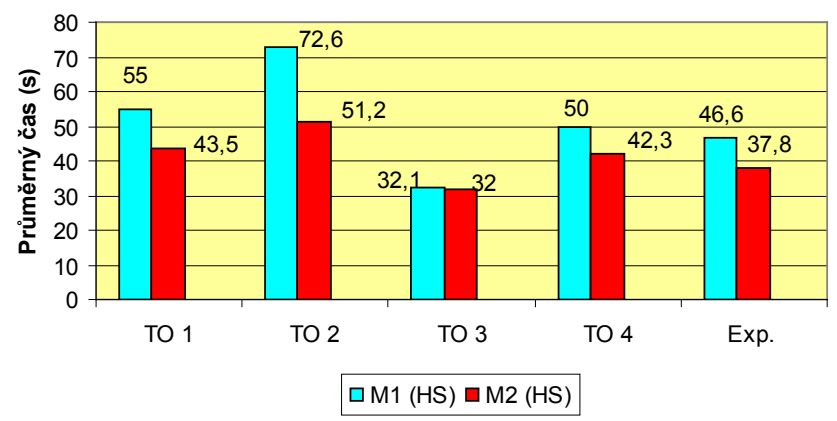

Obr. 5: Graf porovnání výsledků v průměrném čase

Porovnání míry zlepšení v průměrném čase

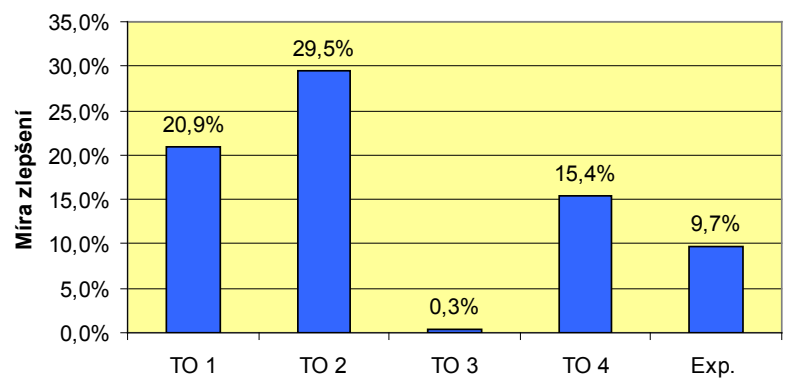

Obr. 6: Graf porovnání míry zlepšení v průměrném čase 
Vysvětlivky:

$M$ - průměrný čas v testu Číselný čtverec;

M1 (HS) - průměrný čas v pretestu (1. testování) vyjádřený v hrubém skóru (sekundách);

M1 (sten) - průměrný čas v pretestu vyjádřený ve stenech;

M2 (HS) - průměrný čas v posttestu (2. testování) vyjádřený v hrubém skóru (sekundách);

M2 (sten) - průměrný čas v posttestu vyjádřený ve stenech;

$M_{\text {diff }}(H S)$ - průmérný rozdil mezi pretestem a posttestem v $M$;

Exp-experimentální skupina - 41 dětí (17 chlapců, 24 děvčat; prưměrný věk 9,43 let);

Míra zlepšení - procentuelní vyjádření změny v prưměrném čase mezi 1. a 2. měrením;

TO - testované osoby (3 chlapci, 1 divka, průmérný věk 9,25 let).

Z výše uvedených dat vyplývá, že nejlepšího výkonu v pretestu v průměrném čase dosáhla TO 3 (32,1 s). Její výkon byl nadprůměrný jak ve vztahu k normě, tak ve vztahu k průměru experimentální skupiny. U TO 3 však nedošlo k téměř žádnému zlepšení. Nejhorší výkon v pretestu dosáhla TO 2 (72,6 s), její výkon odpovídá podprůměrnému výkonu ve vztahu k normě (sten 3 ) i k průměru experimentální skupiny. Zároveň však TO 2 dosáhla největšího zlepšení $(29,5 \%)$, její výkon v postestu odpovídal stenu 5, což považujeme za průměrný výkon vzhledem k normě. Všechny TO kromě TO 3, jejíž výkon už v pretestu byl nadprůměrný, dosáhly výrazného zlepšení oproti průměru ve skupině.

\section{DISKUSE}

V prvopočátku bylo záměrem naší studie provést klasický experiment $\mathrm{s}$ dětmi s ADHD a řešit ho odpovídajícími metodami. Bohužel se nám nepodařilo nalézt homogenní experimentální a kontrolní skupinu, se kterou by výzkum bylo možno provést. Vzhledem k zvýšené míře integrace a inkluze dětí s různými poruchami a vadami do běžné třídy, bývá s nalezením homogenní skupiny problém. Dále jsme narazili na problém provádět intervenční program pouze s užší skupinou dětí s ADHD, které by byly odtrženy od kolektivu v běžné třídě, nebot' by 
musel intervenční program probíhat v jejich volném čase. Po konzultacích s odborníky a zvážení možností realizace výzkumu jsme zvolili variantu kombinace kvantitativně-kvalitativní studie. Děti s poruchami pozornosti jsme ponechali v jejich přirozeném prostředí běžné tř́idy a aplikovali intervenční program na celou třídu, což s sebou nese výhody a zároveň jisté limity naší studie.

\section{ZÁVĚR}

Došli jsme k závěru, že vybrané psychomotorické aktivity mají pozitivní vliv na zlepšení koncentrace a rozsahu pozornosti u dětí mladšího školního věku s ADHD. U všech dětí došlo po aplikaci intervenčního programu ke zlepšení ve všech skórech testů pozornosti. Dále jsme došli $\mathrm{k}$ závěru, že u dětí došlo ke změně vztahu $\mathrm{k}$ pohybové aktivitě na základě charakteristik vzešlých z pozorování, jako je: zvýšení motivace, zájmu o pohybovou aktivitu, snížení strachu a obav z neúspěchu. Na základě interview nám vzešly následující významy, které děti prezentovaly: úspěšnost v pohybové aktivitě, absence výkonové orientace pohybové aktivity, oblíbenost hry. $\mathrm{V}$ tomto ohledu je potřeba dalšího hlubšího kvalitativně orientovaného výzkumu, abychom objevili další významy, které zde díky vlivu psychomotorických aktivit vznikají.

\section{LITERATURA}

Adamírová, J. (2006). Hravá a zábavná výchova pohybem. Základy psychomotoriky. Praha: ČASPV.

American Psychiatric Association (2002). Diagnostic and statistical manual of mental disorders. Dostupné z http://www.psychiatry.org/ publications.

Barkley, R. A. (2006). Attention-deficit hyperactivity disorder: A handbook for diagnosis and treatment. New York: Guilford.

Blahutková, M. (2007). Psychomotorika. Brno: CDVU MU.

Blahutková, M., Klenková, J., \& Zichová, D. (2005). Psychomotorické hry pro děti s poruchami pozornosti a pro hyperaktivni dèti. Brno: MU.

Brossard-Racine M., Majnemer, A. \& Shevell, M. I. (2003). Exploring the Neural Mechanisms that Underlie Motor Difficulties in Children 
with ADHD. Developmental Neurorehabilitation, Vol 14 (2), 101111. Dostupné z: http://web.ebscohost.com/ehost/search/.

Dvořáková, H., Michalová, Z. (2004). Využití psychomotoriky ve škole. PF UK Praha.

Kovářová, K. (2006). Vliv psychomotoriky na rozvoj pozornosti a jemné motoriky sluchově postižené mládeže. Disertační práce. Masarykova univerzita, Fakulta sportovních studií. Vedoucí práce Marie Blahutková. Dostupné z: http://is.muni.cz/th/13785/fsps_d.

Krejčí, M. (2003). Setkánís jógou. Jóga jako prostředek rozvoje zdraví dètí na 1. stupni ZŠ. České Budějovice: EM GRAFIKA s. r. o.

Malá, E. (2001). Hyperkinetické poruchy. Psychiatrie pro praxi; 3, 121124.

Matějček, Z. (2005). Výbor z díla. Praha: Karolinum.

Riccio, C. A., Gonzalez, J. J., \& Hynd, G. W. (1994) Attention-Deficit Hyperaktivity Disorder and Learning Disabilities. Learning Disability Quarterly, Vol. 17, No. 4, 311-322. Dostupné z: http://www.jstor. org/.

Shaywite, J. J. (1988). Physical education programs for children with LD. Journal of Learning Disabilities. Dostupné z: http://www.jstor. org/.

Szabová, M. (1999). Cvičení pro rozvoj psychomotoriky. Praha: Portál.

Trávníková, D. Vliv žonglování a dalšich psychomotorických aktivit na rozvoj motorických dovedností a pozornosti u adolescentu se symptomy ADHD, poruch chování a učení. Disertační práce. Masarykova univerzita, Fakulta sportovních studií. Vedoucí práce Marie Blahutková. Dostupné z: http://is.muni.cz/th/53989/fsps_d/.

Vágnerová, M. (2004). Psychologie problémového ditěte školního věku. Praha: Karolinum.

Weiss, G., Hechtman, L. T. (1993). Hyperactive children grown up. ADHD in Children, Adolescents and Adults. New York: The Guilford Press.

\section{KONTAKT:}

Mgr. Tereza Louková, Ph.D., loukova@seznam.cz 